\title{
Motilitas dan Daya Hidup Spermatozoa Asal Epididimis Sapi Persilangan yang Diencerkan dengan Air Tebu
}

\author{
Muhammad Riyadhi ${ }^{*}$, Muhammad Rizal ${ }^{1}$, Muhammad Thahir ${ }^{2}$ \\ ${ }^{1}$ Jurusan Peternakan, Fakultas Pertanian, Universitas Lambung Mangkurat, \\ Jl. Jend. A. Yani Km.36 Banjarbaru 70714 \\ ${ }^{2}$ Dinas Pertanian Kabupaten Enrekang, \\ Jl. Poros Pinang-Rappang Km. 3 Enrekang 91712 \\ *Email korespondensi: mriyadhi@ulm.ac.id
}

(Diterima 08-10-2019; disetujui 30-12-2019)

\begin{abstract}
ABSTRAK
Air tebu diketahui mengandung sukrosa yang dapat meningkatkan energi bagi motilitas spermatozoa. Penelitian ini bertujuan untuk mengetahui kemampuan air tebu dan kuning telur dalam mempertahankan kualitas spermatozoa asal kauda epididymis sapi persilangan. Penelitian ini menggunakan epididimis sapi persilangan dari rumah pemotongan hewan (RPH) Basirih Kotamadya Banjarmasin. Spermatozoa yang dikoleksi ditempatkan ke dalam empat tabung reaksi masing-masing terdiri dari: $80 \%$ pengencer laktosa $+20 \%$ kuning telur ayam ras (kontrol), $45 \%$ air tebu $+45 \%$ akubidestilata $+10 \%$ kuning telur ayam ras (ATKT10), $42,5 \%$ air tebu $+42,5 \%$ akubidestilata $+15 \%$ kuning telur ayam ras (ATKT15), dan 40\% air tebu $+40 \%$ akubidestilata $+20 \%$ kuning telur ayam ras (ATKT20). Parameter pengamatan adalah motilitas, daya hidup, dan membran plasma utuh. Hasil penelitian menunjukkan motilitas pengencer kontrol (65\%), berbeda nyata $(\mathrm{P}<0,05)$ dengan ATKT10 (49\%), ATKT15 (48\%) dan ATKT20 (54\%), namun demikian ATKT20 masih lebih tinggi $(\mathrm{P}<0,05)$ dengan ATKT10 dan ATKT15. Persentase daya hidup spermatozoa berbeda nyata $(\mathrm{P}<0,05)$ antara kontrol $(79,60 \%)$ dengan ATKT10 $(72,40 \%)$, ATKT15 $(73,20 \%)$, dan ATKT20 $(74,60 \%)$, akan tetapi ATKT20 dan ATKT15 masih lebih baik $(\mathrm{P}<0,05)$ dari ATKT10. Untuk persentase MPU, kontrol sebesar 76,4\%, sama dengan (P>0,05) perlakuan ATKT 20 sebesar 76\%, akan tetapi persentase MPU kontrol masih lebih baik $(\mathrm{P}<0,05)$ dari ATKT 10 sebesar 71,80\% dan ATKT15 sebesar 74,20\%. Dari hasil penelitian ini, terlihat kemampuan air tebu mampu mempertahankan motilitas spermatozoa sampai dengan dua hari.
\end{abstract}

Kata Kunci : air tebu, sapi persilangan, spermatozoa asal kauda epididimis

\begin{abstract}
Sugarcane juice is known to contain sucrose which can increase energy for spermatozoa motility. The object of the study was to determine the ability of sugarcane juice and egg yolk in maintaining the quality of spermatozoa from cauda epididymis of crossbred cattle. This study used epididymal of crossing cattle from the slaughterhouse of Basirih - Banjarmasin. The collected spermatozoa were divided into four test tubes with the same volume in according to the number of treatments i.e.: $80 \%$ lactose $+20 \%$ egg yolk (control), $45 \%$ sugarcane $+45 \%$ aquabidest $+10 \%$ egg yolk (ATKT10), $42.5 \%$ sugarcane $+42.5 \%$ aquabidest $+15 \%$ egg yolk (ATKT15), and $40 \%$ sugarcane $+40 \%$ aquabidest $+20 \%$ egg yolk (ATKT20). The parameter observed included percentage of motility, viability and intact plasma membrane (IPM). The results showed that (1) the percentage of motility $(65 \%)$ and spermatozoa viability $(79.60 \%)$ of control were higher $(\mathrm{P}<0.05)$ than in other treatments, however, ATKT20 had a higher percentage of both parameters than in ATKT10 and ATKT15; (2) the percentage of IPM control $(76.4 \%)$ was not significantly different $(\mathrm{P}>0,05)$ to ATKT20 $(76 \%)$. Both treatments have higher of IPM than ATKT10 (71.80\%) and ATKT15 (74.20\%). The sugarcane juice was able to maintain spermatozoa motility for up to two days.
\end{abstract}

Keywords: crossbred cattle, spermatozoa from cauda epididymis, sugarcane juice 


\section{PENDAHULUAN}

Kemajuan teknologi dibidang reproduksi ternak telah mengalami perkembangan yang sangat pesat. Diawali dengan teknologi inseminasi buatan dengan proses preservasi dan kriopreservasi semen, sampai dengan pemanfaatan sumber benih (spermatozoa) asal kauda epididimis-testis. Laporan pertama (lebih dari 50 tahun yang lalu) kelahiran seekor anak kuda hasil dari inseminasi buatan dengan spermatozoa epididimis (Barker \& Gandier, 1957), memunculkan banyak laporan keberhasilan koleksi, preservasi, dan kriopreservasi spermatozoa asal epididimis pada beberapa jenis ternak, seperti kambing (Lima et al., 2013; Riyadhi et al., 2017), kuda (Monteiro et al., 2011; Roels et al., 2014), rusa (Koziol \& Koziorowski, 2015), serta pada sapi (Agung et al., 2013; Bertol et al., 2013).

Epididimis merupakan sumber spermatozoa yang fertil (Roels et al., 2014). Menurut Guimarães et al., (2012), tidak terdapat perbedaan terhadap morfologi serta viabilitas antara spermatozoa asal epididymis dan hasil ejakulat, akan tetapi motilitas progresif lebih rendah (Guimarães et al., 2012) atau bahkan tidak ada pada semen epididimis (Neild, 2006), namun motilitas dapat kembali menjadi normal apabila spermatozoa kauda epididimis diberikan pengenceran (Senger, 2012).

Proses pengenceran pada semen yang akan dipreservasi maupun kriopreservasi, selain bertujuan untuk meningkatkan volume semen juga untuk mempertahankan kualitas motilitas maupun viabilitas. Bahan pengencer yang umum digunakan pada proses preservasi/kriopreservasi secara umum berasal dari bahan-bahan kimia sintetik, yang dalam pengadaannya memerlukan waktu dan harga yang cukup mahal. Oleh karena itu perlu diperhatikan potensi bahan alami yang dapat berfungsi sebagai bahan pengencer.

Bahan alami alternative yang mudah ditemukan dan murah adalah air tebu. Air tebu mengandung amilum (karbohidrat) berupa sukrosa yang terdiri atas glukosa dan fruktosa (Yovita \& Sumiarsih, 2000). Keberadaan glukosa dan fruktosa merupakan bagian yang penting untuk meningkatkan konsentrasi ATP dan motilitas spermatozoa (Williams \& Ford, 2001).

Namun demikian, terdapat beberapa kelemahan dari penggunaan air tebu yaitu, kemampuan melindungi sel spermatozoa terhadap kejutan dingin pada proses preservasi maupun kriopreservasi. Untuk mengatasi hal tersebut, maka perlu dikombinasikan dengan pengencer lain yang murah dan mudah didapat, semisal kuning telur.
Kuning telur mengandung lesitin dan lipoprotein yang berfungsi sebagai sumber energi dan pelindung ekstraseluler spermatozoa terhadap kejutan dingin (Dwitarizki et al., 2015).

Berbagai laporan mengenai penggunaan pengencer alami yang dikombinasikan dengan pengencer lain telah banyak dilakukan seperti, penggunaan pengencer sari wortel-kuning telur spermatozoa epididimis sapi bali (Parera et al., 2009), air tebu-kuning telur pada semen sapi bali (Bardan, 2009), madu-fosfat kuning telur pada semen kalkun (Sari et al., 2015) dan air kelapakuning telur pada sapi (El-Sheshtawi et al., 2017).

Berdasarkan hasil penelitian diatas, maka penelitian ini dilakukan untuk mengetahui kualitas spermatozoa epididymis sapi persilangan dalam air tebu yang dikombinasikan dengan kuning telur (motilitas, daya hidup dan keutuhan membran plasma).

\section{MATERI DAN METODE}

\section{Tempat dan Waktu}

Penelitian dilaksanakan di Laboratorium Produksi Ternak, Jurusan Peternakan, Fakultas Pertanian Universitas Lambung Mangkurat, Banjarbaru. Testis beserta epididimis sapi persilangan diperoleh di rumah pemotongan hewan (RPH) Basirih Kotamadya Banjarmasin.

\section{Materi}

Materi penelitian ini adalah spermatozoa asal epididimis sapi persilangan. Epididimis dipisahkan dari testis kemudian dimasukkan ke dalam wadah khusus yang telah diisi dengan larutan $\mathrm{NaCl}$ fisiologis $(0,9 \% \mathrm{NaCl})$, sehingga merendam epididimis. Epididimis ditranspor ke laboratorium pada suhu ruang.

\section{Metode}

Penelitian menggunakan metode dalam bentuk rancangan acak lengkap dengan empat perlakuan dan lima kali ulangan. Pengenceran dikelompokkan masing-masing adalah:

Kontrol : 80\% pengencer laktosa $+20 \%$ kuning telur ayam ras (kontrol),

ATKT10 : 45\% air tebu $+45 \%$ akubidestilata + $10 \%$ kuning telur ayam ras

ATKT $15: 42,5 \%$ air tebu $+42,5 \%$ akubidestilata + $15 \%$ kuning telur ayam ras

ATKT20 : 40\% air tebu $+40 \%$ akubidestilata + $20 \%$ kuning telur ayam ras.

Spermatozoa diencerkan hingga konsentrasi 15 juta spermatozoa motil per milliliter. 


\section{Prosedur Penelitian}

Penelitian dilaksanakan melalui beberapa tahapan meliputi persiapan pengencer, koleksi dan pengenceran spermatozoa, serta evaluasi kualitas spermatozoa setelah pengenceran.

\section{Persiapan Pengencer}

Pengencer laktosa disiapkan dengan cara menimbang seluruh komponen yang terdiri atas laktosa dan fruktosa menggunakan timbangan analitik. Pengencer dasar laktosa terdiri dari $9 \mathrm{~g}$ laktosa dan 1,37 $\mathrm{g}$ fruktosa, dilarutkan dengan akuabidestilata hingga mencapai volume $100 \mathrm{ml}$. Sebagai kontrol adalah: $80 \%$ pengencer dasar laktosa $+20 \%$ kuning telur ayam ras + antibiotik (streptomisin dan penisilin) masing-masing 1.000 IU per milliliter pengencer.

Pengencer air tebu disiapkan dengan cara merebus air tebu hingga mendidih. Air tebu yang telah direbus kemudian disaring menggunakan kertas saring dan siap digunakan sebagai bahan pengencer. Pengencer air tebu lengkap terdiri atas: air tebu + akuabidestilata + kuning telur ayam ras + antibiotik (streptomisin dan penisilin) masingmasing 1.000 IU per milliliter pengencer. Persentase air tebu, akuabidestilata, dan kuning telur ayam ras sesuai dengan perlakuan yang dicobakan.

\section{Koleksi dan Pengenceran Spermatozoa}

Koleksi spermatozoa dilakukan dengan teknik slicing, pembilasan, dan penekanan (bilastekan) pada jaringan cauda epididimis (Rizal, 2004), dengan pembilas menggunakan larutan $\mathrm{NaCl}$ fisiologis. Sebelum dibilas-tekan, terlebih dahulu dilakukan penghitungan konsentrasi dengan mengisap spermatozoa menggunakan pipet eritrosit. Spermatozoa hasil koleksi dievaluasi kualitasnya menggunakan mikroskop cahaya untuk menentukan apakah spermatozoa tersebut layak diproses lebih lanjut.

Setelah diyatakan layak, spermatozoa hasil koleksi ditempatkan dalam tabung reaksi berdasarkan kelompok pengencer, ditutup rapat kemudian dimasukkan ke gelas piala yang berisi air bersih dan disimpan di dalam refrigerator lemari es yang bersuhu sekitar $5^{\circ} \mathrm{C}$. Contoh masing-masing perlakuan dievaluasi kualitasnya setiap hari hingga persentase motilitas 40\% (SNI 4869-1, 2017).

\section{Evaluasi Kualitas Spermatozoa}

Evaluasi kualitas spermatozoa dilakukan beberapa tahap, yaitu setelah koleksi (spermatozoa segar) serta setelah pengenceran/preservasi, menggunakan mikroskop cahaya. Evaluasi kualitas spermatozoa segar meliputi: konsentrasi spermatozoa, persentase motilitas, persentase daya hidup, persentase spermatozoa abnormal, dan persentase membran plasma utuh (MPU). Evaluasi kualitas spermatozoa yang telah diencerkan/ dipreservasi meliputi: persentase motilitas, daya hidup, dan MPU.

Persentase motilitas adalah persentase spermatozoa yang bergerak progresif (bergerak ke depan). Variabel ini dievaluasi secara subyektif pada 10 lapang pandang yang berbeda dengan menggunakan lensa objektif pembesaran 400-450X (10x40 atau 10x45) (Arifiantini, 2012). Nilai motilitas berdasarkan proporsi antara gerakan progresif dengan gerakan lain yang dinyatakan dalam persen. Misal proporsi antara gerakan progresif dan lain 7:3, maka nilai motilitasnya adalah sebesar $70 \%$.

Persentase daya hidup dievaluasi dengan pewarnaan eosin $2 \%$ atau eosin nigrosin, dengan perbandingan semen dan pewarna 1:4 untuk sapi dan kerbau (Arifiantini, 2012). Evaluasi dilakuakn dengan mengamati minimum 200 spermatozoa pada mikroskop cahaya dengan pembesaran 400x. Spermatozoa dengan kepala terlihat berwarna putih dinyatakan sebagai spermatozoa hidup, sebaliknya apabila kepala terlihat berwana merah dinyatakan sebagai spermatozoa mati.

Persentase MPU dievaluasi menggunakan metode osmotic resistance test (ORT) (Revell \& Mrode, 1994). Komposisi larutan hipoosmotik terdiri dari 0,9 $\mathrm{g}$ fruktosa $+0,49 \mathrm{~g}$ natrium sitrat, dilarutkan hingga $100 \mathrm{ml}$ dengan akuabidestilata. Dari larutan tersebut, diambil $200 \mu$ l larutan hipoosmotik dan ditambahkan $20 \mu \mathrm{l}$ semen, dihomogenkan dan diinkubasi pada suhu $37^{\circ} \mathrm{C}$ selama 45 menit. Hasil campuran larutan hipoosmotik dan semen yang telah diinkubasi dibuat preparat ulas tipis dengan menggunakan gelas obyek, selanjutnya dievaluasi sebanyak minimum 200 spermatozoa dengan menggunakan mikroskop cahaya pembesaran 400x. Spermatozoa dengan membran plasma utuh akan terlihat dengan ekor melingkar atau menggelembung, sedangkan yang rusak akan terlihat ekor spermatozoa yang lurus.

\section{Analisis Data}

Data dianalisis dengan analisis ragam, perbedaan antarperlakuan diuji dengan uji beda nyata terkecil (Steel \& Torrie, 1993). 


\section{HASIL DAN PEMBAHASAN}

\section{Karakteristik Spermatozoa Segar Kauda Epididimis}

Karakteristik spermatozoa segar kauda epididimis hasil penelitian adalah, rata-rata konsentrasi spermatozoa $1.3120 \mathrm{juta} / \mathrm{ml}$, persentase motilitas $71 \%$, persentase daya hidup $84 \%$, persentase spermatozoa abnormal $8 \%$, dan persentase membran plasma utuh (MPU) $89,5 \%$ (Tabel 1). Nilai ini sudah sudah dapat memenuhi syarat bagi proses selanjutnya, hal ini sesuai dengan pendapat Swellum et al., (2011) dimana motilitas dan abnormalitas semen untuk dapat diproses lebih lanjut berturut-turut diatas $70 \%$ dan $80 \%$. Lebih jauh Revell \& Mrode (1994) melengkapi persyaratan semen untuk proses lebih lanjut, nilai MPU diatas $60 \%$.

Tabel 1. Karakteristik spermatozoa segar kauda epididimis

\begin{tabular}{lr}
\hline Unsur & Rata-rata \pm SD \\
\hline Konsentrasi spermatozoa & $1.310,00 \pm 99,23$ \\
(juta/ml) & \\
Spermatozoa motil $(\%)$ & $71,00 \pm 1,13$ \\
Spermatozoa hidup (\%) & $84,40 \pm 1,87$ \\
Spermatozoa abnormal $(\%)$ & $8,00 \pm 1,12$ \\
Membran plasma utuh $(\%)$ & $89,50 \pm 0,97$ \\
\hline
\end{tabular}

Nilai rata-rata konsentrasi pada penelitian ini (1.3120 juta/ml semen) lebih rendah dari hasil penelitian terdahulu yang dilakukan Labetubun \& Siwa (2011) pada sapi bali dan Bertol et al., (2013) pada sapi Tabapuä Brazil. Perbedaan hasil yang ditemukan dapat dipengaruhi oleh teknik koleksi, individu ternak, umur maupun lingkungan setempat.

Rata-rata motilitas dan daya hidup pada penelitian ini masing-masing adalah $71 \%$ dan $84 \%$, dimana nilai ini sedikit rendah dengan penelitian terdahulu pada sapi persilangan sebesar $72 \%$ (motilitas) dan 85\% (daya hidup) (Rizal et al., 2017) serta pada sapi bali sebesar $75 \%$ (motilitas) dan $86,75 \%$ (daya hidup) (Labetubun \& Siwa, 2011). Menurut Patel et al. (2017) karakteristik semen seekor pejantan yang mempunyai tingkat reproduksi yang baik memiliki nilai motilitas $>60 \%$. Nilai rasio motilitas spermatozoa selalu berbeda dan lebih rendah 5-15\% dibandingkan dengan spermatozoa hidup, hal ini dikarenakan spermatozoa motil sudah pasti hidup, sementara spermatozoa hidup belum tentu motil (Arifiantini, 2012). Hasil rata-rata nilai spermatozoa abnormal penelitian ini sebesar $8 \%$, dimana nilai ini lebih rendah dari penelitian sebelumnya sebesar 10,5\% pada sapi bali (Labetubun \& Siwa, 2011) dan 9,526,5\% pada sapi Tabapuä Brazil (Bertol et al., 2013). Menurut Patel et al. (2017) mempersyaratkan abnormalitas spermatozoa dari seekor pejantan yang baik berkisar antara 8-12\%.

Nilai rata-rata MPU pada penelitian ini adalah $89,5 \%$, dimana nilai ini sedikit lebih tinggi dibandingkan dengan penelitian sebelumnya sebesar 86,75\% pada sapi bali (Labetubun \& Siwa, 2011) dan lebih tinggi dari prasyarat Revell \& Mrode (1994) diatas 60\%.

\section{Kualitas Spermatozoa Kauda Epididimis Selama Preservasi}

Evaluasi kualitas spermatozoa kauda epididimis selama preservasi meliputi persentase motilitas, daya hidup, dan MPU (Tabel 2., Tabel 3., dan Tabel 4.). Dari hasil penelitian yang dilakukan, ditentukan motilitas minimal sebesar $40 \%$, berdasarkan standar SNI 4869-1, 2017, maka pengencer perlakuan pada hari ke-2 dapat mempertahankan motilitas dimana, kontrol $(65 \%)$, berbeda nyata $(\mathrm{P}<0,05)$ dengan ATKT10 $(49 \%)$, ATKT15 (48\%) dan ATKT20 (54\%), namun demikian pengencer ATKT20 masih lebih tinggi $(\mathrm{P}<0,05)$ dibandingkan ATKT10 dan ATKT15.

Dari hasil penelitian ini, terlihat kemampuan air tebu mampu mempertahankan motilitas spermatozoa sampai dengan hari ke-2, hal ini menunjukkan bahwa air tebu memiliki kandungan nutrisi yang diperlukan. Kemampuan air tebu ini mungkin disebabkan karena kandungan air tebu yang terdiri dari sukrosa (18.08\%) dan gula invest $(0,54 \%)$ (Erwinda \& Wahono, 2014). Keberadaan sukrosa dan jenis gula lain, memiliki arti penting di dalam bahan pengencer, yaitu sebagai substrat sumber energi dan krioprotektan ekstraseluler bagi spermatozoa (Herdis et al., 2016). Namun demikian perlakuan kontrol (laktosa-kuning telur) masih lebih baik dibandingkan pengencer dengan air tebu, karena persentase motilitas masih dapat bertahan sampai hari ke-4 penyimpanan. Kemampuan yang lebih baik dari pengencer kontrol mungkin disebabkan karena sifat stabilitas kimia yang terdapat pada pengencer kimia sintetik ini lebih baik dari pengencer perlakuan. Pengencer laktosa merupakan karbohidrat dari golongan disakarida yang terdiri dari satu unit glukosa dan satu unit galaktosa, dimana keduanya dapat di proses melalui siklus Krebs sehingga menghasilkan energi berupa Adenosin Trifosfat (ATP). 
Tabel 2. Rata-rata persentase spermatozoa motil selama preservasi

\begin{tabular}{lccccc}
\hline \multirow{2}{*}{ Perlakuan } & \multicolumn{5}{c}{ Penyimpanan hari ke- } \\
\cline { 2 - 6 } & 1 & 2 & 3 & 4 & 5 \\
\hline Kontrol & $71,00 \pm 1,13$ & $65,00 \pm 0,00^{\mathrm{c}}$ & $48,00 \pm 4,47^{\mathrm{c}}$ & $43,00 \pm 4,47^{\mathrm{c}}$ & $34,00 \pm 2,24^{\mathrm{c}}$ \\
ATKT10 & $71,00 \pm 1,13$ & $49,00 \pm 2,24^{\mathrm{a}}$ & $31,00 \pm 2,24^{\mathrm{a}}$ & $10,00 \pm 0,00^{\mathrm{a}}$ & $0,00 \pm 0,00^{\mathrm{a}}$ \\
ATKT15 & $71,00 \pm 1,13$ & $48,00 \pm 2,74^{\mathrm{a}}$ & $35,00 \pm 5,00^{\mathrm{ab}}$ & $12,00 \pm 2,74^{\mathrm{a}}$ & $2,00 \pm 2,74^{\mathrm{a}}$ \\
ATKT20 & $71,00 \pm 1,13$ & $54,00 \pm 2,74^{\mathrm{b}}$ & $36,00 \pm 4,18^{\mathrm{b}}$ & $18,00 \pm 2,74^{\mathrm{b}}$ & $5,00 \pm 3,54^{\mathrm{b}}$ \\
\hline
\end{tabular}

a,b,c Superskrip yang berbeda dalam kolom yang sama menunjukkan berbeda nyata $(\mathrm{P}<0,05)$

Dari hasil penelitian ini, terlihat kemampuan air tebu mampu mempertahankan motilitas spermatozoa sampai dengan hari ke-2, hal ini menunjukkan bahwa air tebu memiliki kandungan nutrisi yang diperlukan. Kemampuan air tebu ini mungkin disebabkan karena kandungan air tebu yang terdiri dari sukrosa $(18.08 \%)$ dan gula invest $(0,54 \%)$ (Erwinda \& Wahono, 2014). Keberadaan sukrosa dan jenis gula lain, memiliki arti penting di dalam bahan pengencer, yaitu sebagai substrat sumber energi dan krioprotektan ekstraseluler bagi spermatozoa (Herdis et al., 2016). Namun demikian perlakuan kontrol (laktosa-kuning telur) masih lebih baik dibandingkan pengencer dengan air tebu, karena persentase motilitas masih dapat bertahan sampai hari ke-4 penyimpanan. Kemampuan yang lebih baik dari pengencer kontrol mungkin disebabkan karena sifat stabilitas kimia yang terdapat pada pengencer kimia sintetik ini lebih baik dari pengencer perlakuan. Pengencer laktosa merupakan karbohidrat dari golongan disakarida yang terdiri dari satu unit glukosa dan satu unit galaktosa, dimana keduanya dapat di proses melalui siklus Krebs sehingga menghasilkan energi berupa Adenosin Trifosfat (ATP).

Rata-rata persentase daya hidup spermatozoa pada hari ke-2 hasil penelitian menunjukkan perbedaan yang nyata $(\mathrm{P}<0,05)$ antara kontrol $(79,60 \%)$ dengan ATKT10 (72,40\%), ATKT15 $(73,20 \%)$, dan ATKT20 (74,60\%), akan tetapi ATKT20 dan ATKT15 masih lebih baik $(\mathrm{P}<0,05)$ dari ATKT10. Untuk persentase MPU hasil penelitian hari ke-2 kontrol sebesar 76,4\%, sama dengan $(\mathrm{P}>0,05)$ perlakuan ATKT 20 sebesar $76 \%$, akan tetapi persentase MPU kontrol masih lebih baik $(\mathrm{P}<0,05)$ dari ATKT 10 sebesar 71,80\% dan ATKT15 sebesar 74,20\%.

Tabel 3. Rata-rata persentase spermatozoa hidup selama preservasi

\begin{tabular}{lccccc}
\hline \multirow{2}{*}{ Perlakuan } & \multicolumn{5}{c}{ Penyimpanan hari ke- } \\
\cline { 2 - 6 } & 1 & 2 & 3 & 4 & 5 \\
\hline Kontrol & $84,40 \pm 1,87$ & $79,60 \pm 1,60^{\mathrm{c}}$ & $64,20 \pm 3,31^{\mathrm{c}}$ & $52,20 \pm 2,79^{\mathrm{c}}$ & $44,20 \pm 3,35^{\mathrm{c}}$ \\
ATKT10 & $84,40 \pm 1,87$ & $72,40 \pm 2,86^{\mathrm{a}}$ & $50,80 \pm 3,26^{\mathrm{a}}$ & $29,00 \pm 1,41^{\mathrm{a}}$ & $13,00 \pm 2,92^{\mathrm{a}}$ \\
ATKT15 & $84,40 \pm 1,87$ & $73,20 \pm 1,83^{\mathrm{ab}}$ & $50,40 \pm 3,08^{\mathrm{a}}$ & $30,80 \pm 4,37^{\mathrm{ab}}$ & $11,40 \pm 1,67^{\mathrm{a}}$ \\
ATKT20 & $84,40 \pm 1,87$ & $74,60 \pm 1,94^{\mathrm{b}}$ & $53,80 \pm 4,15^{\mathrm{b}}$ & $32,80 \pm 3,33^{\mathrm{b}}$ & $16,40 \pm 4,45^{\mathrm{b}}$ \\
\hline
\end{tabular}

a,b,c Superskrip yang berbeda dalam kolom yang sama menunjukkan berbeda nyata $(\mathrm{P}<0,05)$

Tabel 4. Rata-rata persentase MPU selama preservasi

\begin{tabular}{lccccc}
\hline \multirow{2}{*}{ Perlakuan } & \multicolumn{5}{c}{ Penyimpanan hari ke- } \\
\cline { 2 - 6 } & 1 & 2 & 3 & 4 & 5 \\
\hline Kontrol & $89,50 \pm 0,97$ & $76,40 \pm 3,35^{\mathrm{c}}$ & $67.00 \pm 2,35^{\mathrm{c}}$ & $59.20 \pm 2,35^{\mathrm{b}}$ & $46.20 \pm 1,30^{\mathrm{c}}$ \\
ATKT10 & $89,50 \pm 0,97$ & $71.80 \pm 3,11^{\mathrm{a}}$ & $61.00 \pm 1,58^{\mathrm{a}}$ & $43.60 \pm 1,58^{\mathrm{a}}$ & $25.20 \pm 1,48^{\mathrm{a}}$ \\
ATKT15 & $89,50 \pm 0,97$ & $74.20 \pm 1,67^{\mathrm{b}}$ & $62.80 \pm 0,84^{\mathrm{ab}}$ & $44.00 \pm 0,84^{\mathrm{a}}$ & $25.60 \pm 3,65^{\mathrm{a}}$ \\
ATKT20 & $89,50 \pm 0,97$ & $76.00 \pm 4,45^{\mathrm{bc}}$ & $63.20 \pm 0,84^{\mathrm{b}}$ & $45.20 \pm 0,84^{\mathrm{a}}$ & $28.20 \pm 2,39^{\mathrm{b}}$ \\
\hline
\end{tabular}

a,b,c Superskrip yang berbeda dalam kolom yang sama menunjukkan berbeda nyata $(\mathrm{P}<0,05)$ 
Persentase daya hidup dan MPU berkorelasi positif dengan persentase motilitas karena spermatozoa yang motil sudah tentu memiliki membran plasma yang utuh dan hidup (Riyadhi et al., 2019). Evaluasi daya hidup spermatozoa mempunyai prinsip yang sama dengan MPU, yaitu berdasarkan pada pompa ion ke dalam dan ke luar sel spermatozoa (Graham, 2001). Spermatozoa yang mati memiliki permeabilitas membran yang tinggi dan akan dengan mudah menyerap warna, sebaliknya pada spermatozoa hidup permeabilitas membran masih rendah dan tidak akan menyerap warna. Penurunan daya hidup selalu sejalan dengan motilitas spermatozoa dan selalu lebih tinggi. Ratio penurunan daya hidup dan motilitas pada penelitian ini berkisar antara 14,60-25,20\%, lebih tinggi dari rasio yang disampaikan Arifiantini (2012) antara 5$15 \%$.

Dari hasil penelitian yang dilakukan, terlihat kemampuan pengencer kontrol (laktosa-kuning telur) masih lebih baik dibandingkan perlakuan. Hal ini dimungkinkan karena selama proses preservasi laktosa dapat berfungsi sebagai sumber energi dan perlindungan bagi sel spermatozoa (Riyadhi et al., 2017). Menurut Rizal (2009) menyatakan energi yang diperoleh oleh spermatozoa didapat melalui metabolisme glikolisis laktosa sehingga menghasilkan ATP yang dipergunakan untuk motilitas serta memper-tahankan daya hidup. Lebih jauh peranan karbohidrat (gula) penting dalam perlindungan ekstraseluler, sehingga mampu melindungi membrane sel dari kerusakan (Herdis et al., 2016).

\section{KESIMPULAN}

Dari hasil penelitian yang dilakukan, dapat disimpulkan bahwa air tebu mampu mempertahankan motilitas spermatozoa asal kauda epididimis sampai dengan dua hari, dan dosis pengencer air tebu+kuning telur terbaik terdapat pada ATKT 20.

\section{DAFTAR PUSTAKA}

Agung, B., W. Handang, \& M. Mirandy, P.S. 2013. Peningkatan kualitas post thawing spermatozoa epididimis sapi dengan suplementasi catechin sebagai antioksidan pada pengencer semen. J Ilmu Ternak 13:3436.

Arifiantini, R.I. 2012. Teknik Koleksi dan Evaluasi Semen Pada Hewan. IPB Press. Bogor.

Bardan, Feradis, \& T. Adelina. 2009. Penggunaan air tebu yang dikombinasikan dengan kuning telur sebagai pengencer semen sapi bali. J. Peternakan 6:36-43.

Barker, C. \& J. Gandier. 1957. Pregnancy in a mare resulting from frozen epididymal spermatozoa. Canadian $\mathrm{J}$ of Comparative Med and Vet. Sci 21: 47.

Bertol, M.A.F., R.R. Weiss, V. Thomas-Soccol, L.E. Kozicki, A.S. Fujita, R.A. de Abreu, \& K.T. Green. 2013. Viability of bull spermatozoa collected from epididymis stored at $18-20^{\circ} \mathrm{C}$. Braz Arch Biol Technol 56:777-783.

Dwitarizki, N., D. Ismaya, \& W. Asmarawati. 2015. Pengaruh pengenceran sperma dengan air kelapa dan aras kuning telur itik serta lama penyimpanan terhadap motilitas dan viabilitas spermatozoa domba garut pada penyimpanan $5^{\circ} \mathrm{C}$. Buletin Peternakan 39: 149-156.

El-Sheshtawi, R.I., W.S. El-Nattat \& G.A.D. Ali. 2017. Cryopreservation of semen cattle using coconut water extender with different glycerol concentrations. Asian Pacific J of Repro 6:279-282.

Erwinda, M.D. \& H. Wahono. 2014. The effect of lime concentration addition and cane juice ph value on brown sugar quality. J Pangan dan Agroindustri 2: 54-64.

Graham, J.K. 2001. Assessment of Sperm Quality. Proceedings AAEP 47:302-305.

Herdis, W.A. Darmawan, \& M. Rizal. 2016. Penambahan beberapa jenis gula dapat meningkatkan kualitas spermatozoa beku asal epididimis ternak domba. J Kedokteran Hewan 10: 200-204.

Guimarães, T., G. Lopes, P. Ferreira, I. Leal \& A. Rocha. 2012. Characteristics of stallion epididymal spermatozoa at collection and effect of two refrigeration protocols on the quality of the frozen/thawed sperm cells. Anim Repro Sci 136: 85-89.

Koziol, K. \& M. Koziorowski. 2015. Morphological defects of epididymal spermatozoa in male roe deer (Capreolus capreolus) during the reproductive season. Polish J of Vet Sciences 18:562-572.

Labetubun, J. \& I.P. Siwa. 2011. Kualitas spermatozoa epididimis sapi bali dengan penambahan laktosa atau maltosa yang 
dipreservasi pada suhu $3-5^{\circ} \mathrm{C}$. J Vet $12: 200-$ 207.

Lima, I.C.S., I.R.A. Andrade, G.V. Aguiar, M.M. Silva, A.G.V. Catunda, G.A. Martins, C.R.F. Gadelha, \& A.C.N. Campos. 2013. In vitro evaluation of goat cauda epididymal sperm, cooled in different extenders at $4^{\circ} \mathrm{C}$. Arch Zootec 62:429-437.

Monteiro, G.A., F.O. Papa, F.S. Zahn, J.A. Dellaqua Jr., C.M. Melo, R.R.D. Maziero, B.R. Avanzi, M.A. Alvarenga \& P.N. Guasti. 2011. Cryopreservation and fertility of ejaculated and epididymal stallion sperm. Anim Repro Sci 127:197-201.

Neild, D. 2006. Cryopreservation of cauda epididymis spermatozoa from slaughterhouse testicles 24 hours after ground transportation. Anim Repro Sci 94: 92-95.

Parera, F., Z. Prihatiny, D.F. Souhoka, \& M. Rizal. 2009. Pemanfaatan sari wortel sebagai pengencer alternatif spermatozoa epididimis sapi bali. J Indon Trop Agric 34:50-56.

Patel, G.K., N. Haque, M. Madhavatar, A.K. Chaudhari, D.K. Patel, N. Bhalakiya, N. Jamnesha, P. Patel, \& R. Kumar. 2017. Artificial insemination: A. Tool to improve livestock productivity. J of Pharmacognosy and Phytochemistry SP1:307-313.

Revell, S.G. \& R.A. Mrode. 1994. An osmotic resistance test for bovine semen. Anim Repro Sci 36:77-86.

Riyadhi, M., A. Setiawan, Herdis, \& M. Rizal. 2017. Epididymal spermatoza quality of etawa crossbreed goat in tris extender supplemented with various lactose concentration. J Ked Hewan 11:15-18.

Riyadhi, M., A. Wahdi, \& M. Rizal. 2019. Kriopreservasi semen kambing boer dengan konsentrasi pengencer nira aren dan gliserol berbeda. J Ilmu Teknologi Peternakan Tropis 6:1-7.

Rizal, M. 2004. Penyimpanan epididimis pada Suhu $5^{\circ} \mathrm{C}$ selama tiga hari: pengaruhnya terhadap kualitas spermatozoa yang telah dibekukan. Media Kedokteran Hewan 20:57-61.

Rizal, M. 2009. Daya hidup spermatozoa epididimis sapi bali yang dipreservasi pada suhu $3-5^{\circ} \mathrm{C}$ dalam pengencer tris dengan konsentrasi laktosa yang berbeda. J Ilmu Ternak dan Vet 14:142-149.

Rizal, M., M. Riyadhi, B. Irawan, A. Wahdi, Habibah, \& Herdis. 2017. Daya hidup spermatozoa epididimis sapi persilangan yang dipreservasi dengan air kelapa muda pada suhu $5^{\circ} \mathrm{C}$. J Vet 18:571-579.

Roels, K., B. Leemans, C. Ververs, J. Govaere, M. Hoogewijs, \& A. Van Soom. 2014. Collection and freezing of equine epididymal spermatozoa. Vlaams Diergeneeskundig Tijdschrift 83:321-325.

Sari, N.M.D.P, W. Bebas, \& I.G.N.B. Trilaksana. 2015. Madu meningkatkan kualitas semen kalkun selama penyimpanan. Buletin Veteriner Udayana 7: 164-171.

Senger, P.L. 2012. Pathways to Pregnancy and Parturition. $3^{\text {rd }}$ Ed. Current Conceptions, Inc. Pullman.

Standar Nasional Indonesia (SNI). 2017. SNI 48691, Semen Beku-Bagian 1: Sapi. Badan Standardisasi Nasional. Jakarta.

Steel, R.G.D. \& J.H. Torrie.1993. Prinsip dan Prosedur Statistik, Suatu Pendekatan Biometrik. Terjemahan Sumantri, B. Gramedia Pustaka Utama. Jakarta.

Swellum, A.A., H.A. Mansour, A.A. Elsayed, \& H.A. Amer. 2011. Comparing ethylene glycol with glycerol for cryopreservation of buffalo bull semen in egg-yolk containing extenders. Theriogenology 76:833-842.

Williams, A.C. \& W.C.L. Ford. 2001. The role of glucose in supporting motility and capacitation in human spermatozoa. $\mathbf{J}$ of Andrology 22: 680-695.

Yovita \& Sumiarsih. 2000. Pembudidayaan Tebu di Lahan Sawah dan Tegalan. Penebar Swadaya. Surabaya. 